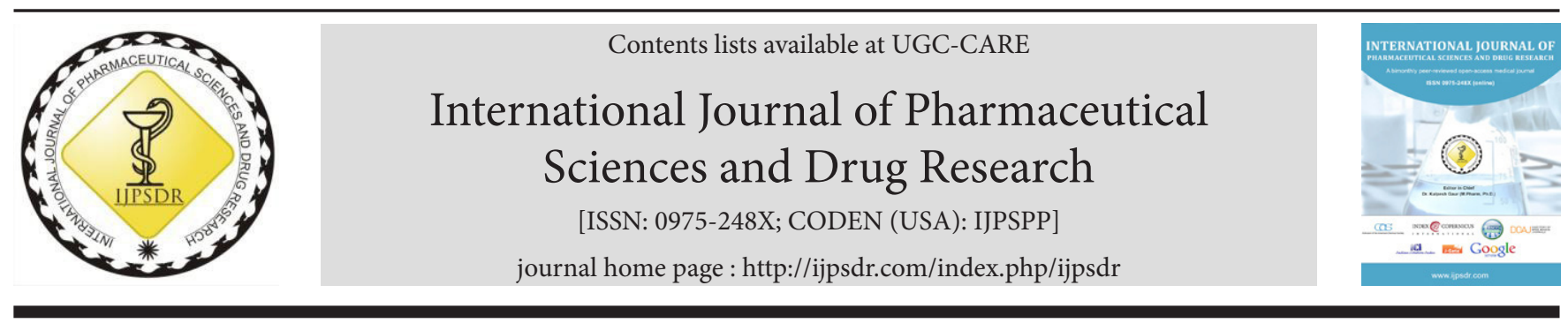

Research Article

\title{
Pharmacokinetic and Pharmacodynamic Interactions between Concomitantly used Gliclazide with Pravastatin
}

\author{
T S Abdul Haseeb, T Rama Mohan Reddy* \\ Department of Pharmacy, Mewar University, Chittorgarh-312901, Rajasthan, India
}

\begin{tabular}{l} 
A R T I C L E I N F O \\
\hline Article history: \\
Received: 02 October, 2020 \\
Revised: 29 October, 2020 \\
Accepted: 04 November, 2020 \\
Published: 30 November, 2020 \\
Keywords: \\
Diabetic Hyperlipidemia, \\
Gliclazide, \\
Pharmacodynamics, \\
Pharmacokinetic, \\
Pravastatin. \\
D0I: \\
10.25004/IJPSDR.2020.120612
\end{tabular}

\section{INTRODUCTION}

The potential Drug-Drug Interaction (DDI) refers to the prospect of drug to modify the effects of another drug, being administered, simultaneosly. ${ }^{[1]}$ It is a common medical practice to use drug combinations with the potential to interact. Not all DDIs are potential in nature, hence their detection is significant as they may increase the risk of adverse drug reactions (ADRs), loss of drug efficacy, which also causes adverse consequences for patients in increasings duration of hospital stay and cost. $^{[2,3]}$

\begin{abstract}
A B S T R A C T
Diabetic hyperlipidemia is associated with increased lipoproteins in the blood hence, the introduction of a lipid lowering drugs aids in controlling the same. This comedication may lead to drug-drug interactions between anti-diabetic and anti-hyperlipidemic drugs. The current research is aimed at evaluating the pharmacodynamic and pharmacokinetic interactions of gliclazide (anti-diabetic) therapy by pravastatin (anti-hyperlipidemic) when administrated in combination. The studies conducted on rats dosed with gliclazide, pravastatin individually and in combination. Statistical comparisons of plasma concentration - response study in groups with gliclazide alone, pravastatin alone and in combination was carried out. The response study among concentrations and time were calculated employing student's paired T-Test. The results indicate that gliclazide is completely absorbed with peak plasma concentration of $6.82 \pm 0.12$ $\mathrm{ng} / \mathrm{mL}$ and $7.82 \pm 0.12 \mathrm{ng} / \mathrm{mL}$ when administrated alone and $7.22 \pm 0.12 \mathrm{ng} / \mathrm{mL}$ and $7.22 \pm 0.12$ when administrated in combination in diabetic rats on first day (day 1) and eighth day (day8) respectively. Similarly, peak plasma concentration of pravastatin is $3.92 \pm 0.03 \mathrm{ng} / \mathrm{mL}$ and $4.80 \pm 0.04 \mathrm{ng} / \mathrm{mL}$ when administrated alone and $3.683 \pm 0.02 \mathrm{ng} / \mathrm{mL}$ and $4.657 \pm 0.04 \mathrm{ng} / \mathrm{mL}$ when administrated in combination in diabetic rats on first day (day 1) and eighth day (day 8) respectively. There was no statistically noteworthy variation observed in peak plasma concentration $(p>0.05)$. Similarly, no variations observed in values of $\mathrm{t}_{\max }, \mathrm{AUC}$ and $\mathrm{T}_{1 / 2}$. The fasting serum glucose concentrations in normal and STZ-induced diabetic group on first day (day 1) and eighth day (day 8) were analyzed. The reduction of blood glucose levels at different time intervals on administration of gliclazide and pravastatin alone and in combination analyzed and results indicate no significant change in pharmacodynamic parameters.

Hence the results conclude that combinational therapy of gliclazide and pravastatin were found safe and highly potential in treating hyperlipidemia patients.
\end{abstract}

\footnotetext{
${ }^{*}$ Corresponding Author: T Rama Mohan Reddy

Address: Department of Pharmacy, Mewar University, Chittorgarh-312901, Rajasthan, India

Email $₫$ : roshansalfi@yahoo.com

Tel.: +91-8686377725

Relevant conflicts of interest/financial disclosures: The authors declare that the research was conducted in the absence of any commercial or financial relationships that could be construed as a potential conflict of interest.

Copyright (C) 2020 T S Abdul Haseeb et al. This is an open access article distributed under the terms of the Creative Commons AttributionNonCommercial-ShareAlike 4.0 International License which allows others to remix, tweak, and build upon the work non-commercially, as long as the author is credited and the new creations are licensed under the identical terms.
}

In recent days the number of patients suffering from atherosclerosis and other cardiac disorders is rising. Diabetes mellitus, also known as "hyperglycemia", is marked by increase in blood glucose. Type I and Type II are two types of diabetes with 5 and 95\% prevalence, respectively. Type II diabetics lead to obesity in $60 \%$ of the cases according to World Health Organization (WHO) which is 1.5 times higher in patients with dyslipidemia. This leads to the need of lipid lowering drugs for treatment of dyslipidemia. This may lead to -drug interactions between anti-diabetic and anti-hyper lipidemic drugs. 
Sulfonylureas are used for type II diabetic treatment. Gliclazide, which belongs to second generation sulfonylureas, is used widely due to its selective inhibition towards pancreatic K+ATP channels, ${ }^{[4]}$ fewer prevalence of causing severe hypoglycemia ${ }^{[5]}$ and related haemobiological effects. ${ }^{[6] \text {. }}$

Pravastatin is used for treatmentofhyper triglyceridemia, and dysbetalipoproteinemia ${ }^{[7]}$ also known for preventing cardiovascular events. ${ }^{[8]}$ Pravastatin is metabolized by $\mathrm{P}$ 450 CYP 3A4 \& CYP 3A5 isozymes in the liver. ${ }^{[9-11]}$

The objective of current research is to understand the pharmacokinetic and pharmacodynamic drug interaction amongst gliclazide and pravastatin, when used in combination.

\section{Materials AND METhods}

\section{Material}

Gliclazide and pravastatin were obtained from Aurabindo laboratories.

Analytical grade Methanol was obtained from Finar chemicals Ltd. Ahmadabad.

Other analytical grade solventswere used.

\section{Animal Preparation}

Twenty-four male Wistar rats (weigh 200-220 g) were segregated into five different groups of six animals, each. The animals were maintained at 50\% RH, fed with ad libitum and water. The protocol was approved by institutional animal ethics committee.

\section{Induction of Experimental Diabetes}

The animals were fasted for about 16 hours prior induction of diabetes using Streptozotocin (STZ), for induction of Type-1 diabetes mellitus.

Six animals were injected intraperitoneally with $0.23-0.25 \mathrm{ml}$ of freshly prepared STZ solutions $(60 \mathrm{ng} / \mathrm{mL}$ in $0.01 \mathrm{M}$ citrate buffer of $\mathrm{pH} 4.5$ ) at a final dosage of $60 \mathrm{mg} / \mathrm{kg}$ body weight. The diabetic state analyzed STZtreated animals by measuring glucose concentration in non-fasting serum post 48 hours. Only animals with serum glucose levels $>300 \mathrm{mg} / \mathrm{fdL}$ were chosen for experiment.

\section{Study Design ${ }^{[12]}$}

Animals were categorized into five groups of six each Group I : Control group

Group II : Diabetic control group

Group III : Gliclazide administrated as single dosage/day in diabetic rats

Group IV : Pravastatin administrated as single dosage/day in diabetic rats

Group V : Gliclazide and pravastatin concomitant administrated as a single dosage/ day in diabetic rats

\section{Preparation of Drug Solutions}

\section{Preparation of Gliclazide}

A total of $80 \mathrm{mg}$ of pure gliclazide dissolved in $0.5 \%$ of carboxy methyl cellulose. This makes a solution of $8 \mathrm{mg} / \mathrm{mL}$ concentration.

\section{Preparation of Pravastatin}

A total of $40 \mathrm{mg}$ of pure pravastatin suspended into $10 \mathrm{~mL}$ of carboxy methyl cellulose $(0.5 \%)$ to obtain final solution of $4 \mathrm{mg} / \mathrm{mL}$ concentration for immediately use.

\section{Blood samples collection procedure}

A total of $0.5 \mathrm{~mL}$ blood sample drawn from each anesthetized rat. The samples collected using capillary tube from retro-orbital plexus with $20 \mu \mathrm{L}$ of $10 \%$ disodium ethylene diamine tetracaetate salt.

The blood samples collected at specified intervals of $0.5,1,2,4,6,8,10,12,16$ and 24 hours. Each blood withdrawal is followed by administration of saline. The blood samples centrifuged for 5 minutes at 2500 $3000 \mathrm{rpm}$. The plasma obtained is stored in pre labeled centrifuge tubes at $-30^{\circ} \mathrm{C}$.

The same procedure was followed on first day and eighth day. The data analyzed using Win Nonlin $\AA 5.1$ software. ${ }^{[13,14]}$

\section{Plasma Sample Preparation for HPLC Analysis}

A total of $0.5 \mathrm{~mL}$ of plasma sample was precipitated for protein by adding $2.5 \mathrm{~mL}$ cold ethanol. The contents were centrifuged and precipitate was resuspended by adding $1 \mathrm{~mL}$ acetonitrile followed by vertexing for 60 seconds. The contents were centrifuged for 10 minutes at 5000-6000 rpm, organic layer separate and dried over nitrogen. The samples added to $200 \mathrm{~mL}$ of ACN and water in 70:30 ratio for reconstitution. Those samples were used for HPLC injection.

\section{Pharmacokinetic (PK) analysis}

The concentration time data used to obtain $\mathrm{C}_{\max }$ and $\mathrm{t}_{\max }$ values. The $\mathrm{AUC}_{0-\mathrm{t}}$ measured from $0-24$ hours and $\mathrm{AUC}_{0-\alpha}$

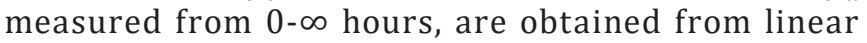
trapezoidal rule. $\mathrm{The}^{\mathrm{AUC}_{0-\alpha}}$ is calculated using the formula $\mathrm{AUC}_{0-\mathrm{t}}+\left[\mathrm{C}_{\text {last }} / \mathrm{K}\right]$

$\mathrm{C}_{\text {last }}$ - concentration at last time point $(\mathrm{ng} / \mathrm{mL})$

$\mathrm{K}$-elimination rate constant

The parameters including volume of distribution (V/f), AUC, elimination half-life $\left[\mathrm{t}^{1} / 2\right]$, total clearance $(\mathrm{Cl} / \mathrm{f})$ and mean residence time.

\section{Statistical Analysis}

Statistical comparisons of gliclazide, pravastatin alone and in combination groups plasma concentration-response study among various concentrations and time carried out using student's paired t-test a value of $\mathrm{P}<0.05$ was considered to be statistically significant. 


\section{RESULTS}

\section{Study of Plasma Level Concentrations of Gliclazide and Pravastatin}

Plasma level (ng/mL) of gliclazide alone and in combination with pravastatin on first day (day 1) were found at various time intervals till 24 hours and the plasma concentrations of gliclazide alone on first day (day 1 ) are $0 \pm 0,0.77 \pm 0.39$, $2.88 \pm 0.24,4.34 \pm 0.14,6.82 \pm 0.12,4.22 \pm 0.37,3.62 \pm 0.95$, $2.25 \pm 0.23,1.82 \pm 0.34,0.12 \pm 0.43,0 \pm 0$ respectively and gliclazide combined with pravastatin $0 \pm 0,1.77 \pm 0.39,3.28$ $\pm 0.24,4.64 \pm 0.14,7.22 \pm 0.12,5.22 \pm 0.37,4.62 \pm 0.95,2.75$ $\pm 0.23,1.62 \pm 0.34,0.52 \pm 0.43,0 \pm 0$ respectively.

The plasma levels $(\mathrm{ng} / \mathrm{mL}$ ) of gliclazide alone and in combination with pravastatin on eighth day (day 8) were found the concentrations are various time intervals till 24 $\mathrm{h}$ and the plasma concentrations of gliclazide alone $0.77 \pm$ $0.39,2.37 \pm 0.39,3.88 \pm 0.24,5.34 \pm 0.14,7.82 \pm 0.12,5.22$ $\pm 0.37,4.62 \pm 0.95,3.25 \pm 0.23,2.82 \pm 0.34,1.12 \pm 0.43$, $0.11 \pm 0.01$ respectively and gliclazide in combination with pravastatin $0.97 \pm 0.39,1.77 \pm 0.39,3.28 \pm 0.24,4.64$ $\pm 0.14,7.22 \pm 0.12,5.22 \pm 0.37,4.62 \pm 0.95,2.75 \pm 0.23,1.62$ $\pm 0.34,0.52 \pm 0.43,0.32 \pm 0.02$ respectively.

The plasma level $(\mathrm{ng} / \mathrm{mL})$ of pravastatin alone and in combination with gliclazide on first day (day 1) was found the concentrations at various time intervals till 24 hours and the plasma concentrations of pravastatin alone on first day (day 1) are $0 \pm 0,0.71 \pm 0.03,3.92 \pm 0.03,2.95 \pm 0.01$, $1.54 \pm 0.06,1.16 \pm 0.01,0.92 \pm 0.02,0.74 \pm 0.01,0.56 \pm 0.01$, $0 \pm 0,0 \pm 0$ respectively, pravastatin in combination with gliclazide on first day (day 1) $0 \pm 0,0.885 \pm 0.04,3.683 \pm$ $0.02,2.836 \pm 0.03,1.416 \pm 0.04,1.233 \pm 0.01,0.78 \pm 0.02$, $0.32 \pm 0.02,0.12 \pm 0.01,0 \pm 0,0 \pm 0$ respectively.

Plasma levels $(\mathrm{ng} / \mathrm{mL})$ of pravastatin alone and in combination with gliclazide on eighth day (day 8) were found the concentrations at various time intervals till 24 hours and the plasma concentrations of pravastatin alone

Table 1: Peak plasma concentrations of gliclazide $(\mathrm{ng} / \mathrm{mL})$ and its combination with pravastatin on first day (Day 1)

\begin{tabular}{lll}
\hline Time $(h)$ & Gliclazide alone & $\begin{array}{l}\text { Gliclazide combination with } \\
\text { Pravastatin }\end{array}$ \\
\hline 0 & $0 \pm 0$ & $0 \pm 0$ \\
0.5 & $0.77 \pm 0.39$ & $1.77 \pm 0.39$ \\
1 & $2.88 \pm 0.24$ & $3.28 \pm 0.24$ \\
2 & $4.34 \pm 0.14$ & $4.64 \pm 0.14$ \\
4 & $6.82 \pm 0.12$ & $7.22 \pm 0.12$ \\
6 & $4.22 \pm 0.37$ & $5.22 \pm 0.37$ \\
8 & $3.62 \pm 0.95$ & $4.62 \pm 0.95$ \\
10 & $2.25 \pm 0.23$ & $2.75 \pm 0.23$ \\
12 & $1.82 \pm 0.34$ & $1.62 \pm 0.34$ \\
16 & $0.12 \pm 0.43$ & $0.52 \pm 0.43$ \\
24 & $0 \pm 0$ & $0 \pm 0$ \\
\hline
\end{tabular}

on eighth day (day 8) are $0.54 \pm 0.09,0.94 \pm 0.01,4.80 \pm$ $0.04,3.61 \pm 0.13,2.34 \pm 0.03,1.71 \pm 0.04,1.23 \pm 0.02,0.93$ $\pm 0.01,0.56 \pm 0.02,0 \pm 0,0 \pm 0$ respectively, pravastatinin combination with gliclazide on eighth day (day 8) are 0.505 $\pm 0.02,0.848 \pm 0.01,4.165 \pm 0.04,3.568 \pm 0.08,2.261 \pm$ $0.03,1.538 \pm 0.07,1.32 \pm 0.02,1.02 \pm 0.03,0.66 \pm 0.04,0 \pm$ $0,0 \pm 0$ respectively.

The mean \pm standard error mean (S.E.M) of plasma concentration of gliclazide alone on first day (day 1) at different time points compared with combination treatment of pravastatin and pravastatin on first day (day 1) is shown in Fig. 1 and Table 1. Similarly eighth day (day 8) plasma concentrations were shown in Fig. 2 and Table 2.

The mean \pm standard error mean (S.E.M) of plasma concentration of pravastatin alone on first day (day 1) at different time points compared with combination treatment of pravastatin and gliclazide on first day (day 1) is shown in Fig. 3 and Table 3. Similarly eighth day (day 8) plasma concentrations were shown in Fig. 4 and Table 4 .

In the present study, complete absorption of gliclazide observed orally with peak plasma concentrations of $6.82 \pm 0.12 \mathrm{ng} / \mathrm{mL}$ post 4 hours on first day (day 1 ) when administrated alone and $7.22 \pm 0.12 \mathrm{ng} / \mathrm{mL}$ occurred 4 hours after dosing when administrated in combination

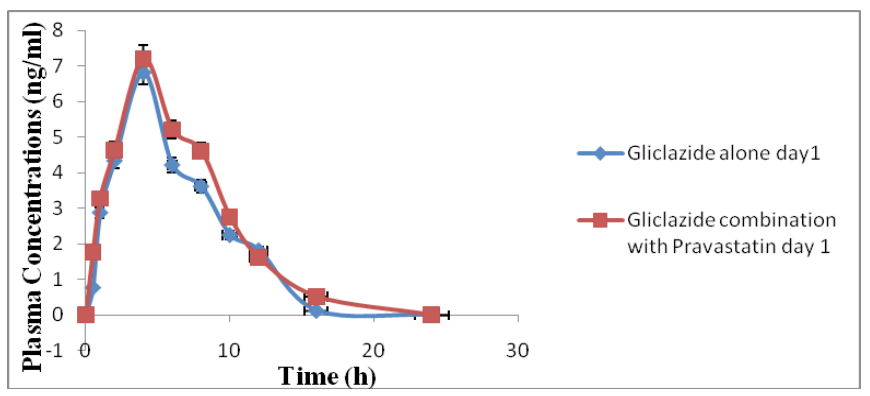

Fig. 1: Plasma levels of gliclazide $(\mathrm{ng} / \mathrm{mL})$ its combination with pravastatin on first day (day 1 )

Table 2: Peak plasma concentration of gliclazide $(\mathrm{ng} / \mathrm{mL})$ and combined with pravastatin on eighth day (Day 8)

\begin{tabular}{lll}
\hline Time $(h)$ & Gliclazide alone & $\begin{array}{l}\text { Gliclazide combination with } \\
\text { Pravastatin }\end{array}$ \\
\hline 0 & $0.77 \pm 0.39$ & $0.97 \pm 0.39$ \\
0.5 & $2.37 \pm 0.39$ & $1.77 \pm 0.39$ \\
1 & $3.88 \pm 0.24$ & $3.28 \pm 0.24$ \\
2 & $5.34 \pm 0.14$ & $4.64 \pm 0.14$ \\
4 & $7.82 \pm 0.12$ & $7.22 \pm 0.12$ \\
6 & $5.22 \pm 0.37$ & $5.22 \pm 0.37$ \\
8 & $4.62 \pm 0.95$ & $4.62 \pm 0.95$ \\
10 & $3.25 \pm 0.23$ & $2.75 \pm 0.23$ \\
12 & $2.82 \pm 0.34$ & $1.62 \pm 0.34$ \\
16 & $1.12 \pm 0.43$ & $0.52 \pm 0.43$ \\
24 & $0.11 \pm 0.01$ & $0.32 \pm 0.02$ \\
\hline
\end{tabular}


Pharmacokinetic and Pharmacodynamic Interactions between Concomitantly used Gliclazide with Pravastatin

Table 3: Peak plasma concentration of pravastatin (ng/mL) and combined with gliclazide on first day (Day 1)

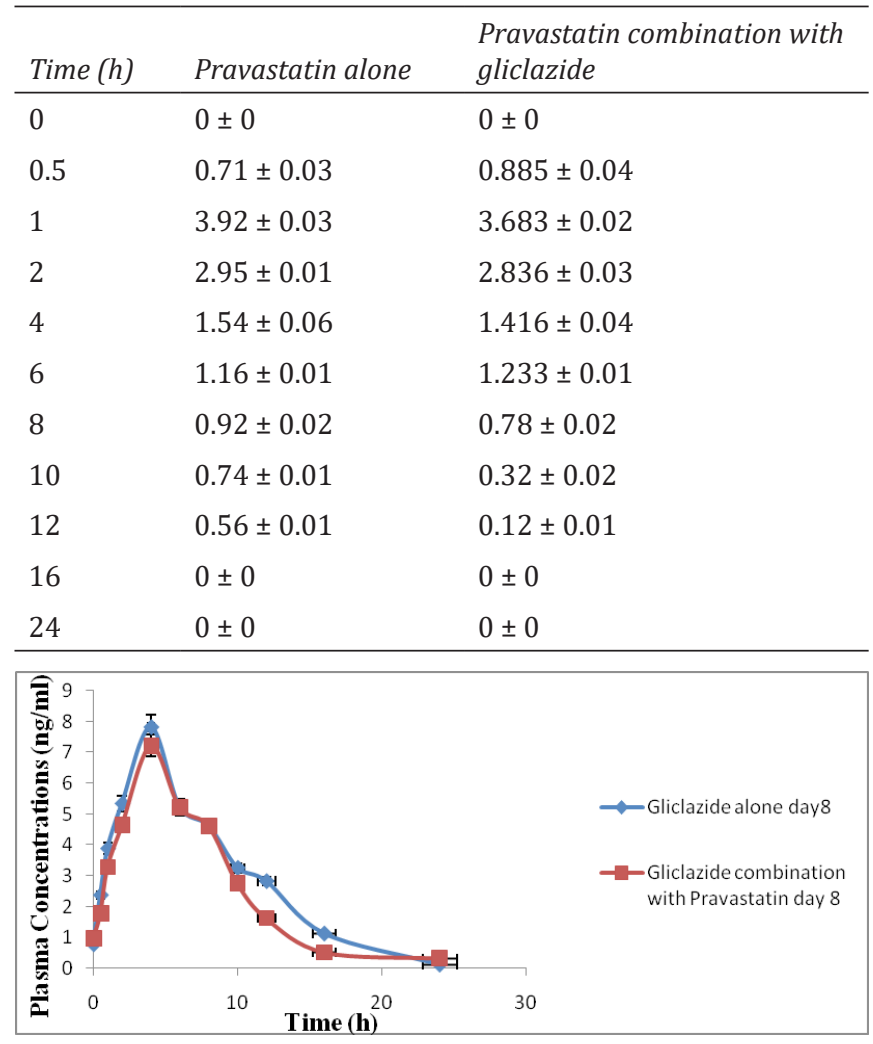

Fig.2: Plasma levels of gliclazide $(\mathrm{ng} / \mathrm{mL})$ and combined withpravastatin on eighth day (day 8)

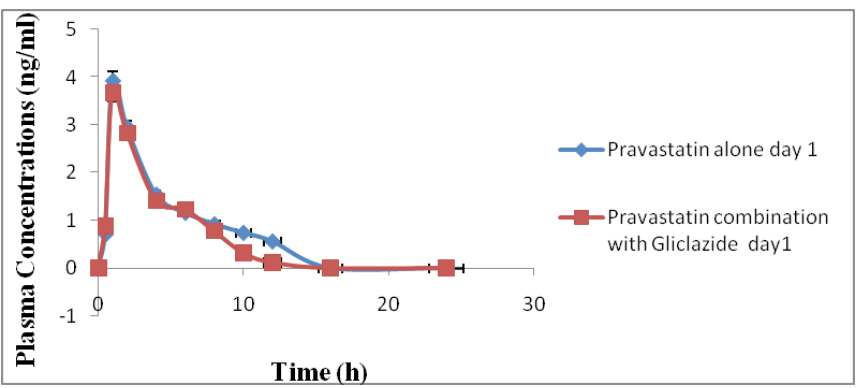

Fig. 3: Plasma level of pravastatin (ng/mL) and combined with gliclazide on first day (day 1)

Day 1 can be separated either in bracket like (Day 1) or with hyphen; in all figures

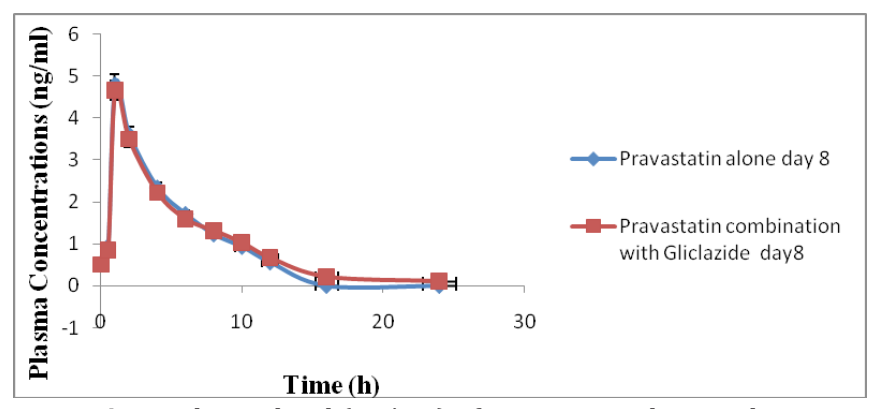

Fig. 4: Plasma level $(\mathrm{ng} / \mathrm{mL})$ of pravastatin alone and in combination with gliclazide on eighth day (day 8)

with pravastatin indicating no significant difference. Complete absorption of pravastatin observed orally with
Table 4: Peak plasma concentration (ng/mL) of pravastatin alone and in combination with gliclazide on eighth day (Day 8)

\begin{tabular}{lll}
\hline Time $(h)$ & Pravastatin alone & Pravastatin with gliclazide \\
0 & $0.54 \pm 0.09$ & $0.505 \pm 0.02$ \\
0.5 & $0.94 \pm 0.01$ & $0.848 \pm 0.01$ \\
1 & $4.80 \pm 0.04$ & $4.657 \pm 0.04$ \\
2 & $3.61 \pm 0.13$ & $3.487 \pm 0.08$ \\
4 & $2.34 \pm 0.03$ & $2.212 \pm 0.03$ \\
6 & $1.71 \pm 0.04$ & $1.583 \pm 0.07$ \\
8 & $1.23 \pm 0.02$ & $1.312 \pm 0.02$ \\
10 & $0.93 \pm 0.01$ & $1.02 \pm 0.03$ \\
12 & $0.56 \pm 0.02$ & $0.66 \pm 0.04$ \\
16 & $0 \pm 0$ & $0.21 \pm 0.02$ \\
24 & $0 \pm 0$ & $0.10 \pm 0.01$ \\
\hline
\end{tabular}

peak plasma concentrations of $3.92 \pm 0.03 \mathrm{ng} / \mathrm{mL}$ observed 1 hour post dosage on first day (day 1) when administrated alone and $3.783 \pm 0.02 \mathrm{ng} / \mathrm{mL}$ occurred 1 hours after dosing when administrated in combination with gliclazide indicating no major difference in values.

The peak plasma concentration of gliclazide on eighth day (day 8) is $7.82 \pm 0.12$ and combination of gliclazide with pravastatin is $7.22 \pm 0.12 \mathrm{ng} / \mathrm{mL}$. The values for pravastatin on eighth day (day 8) and combination with gliclazide concentration are $4.80 \pm 0.04 \mathrm{ng} / \mathrm{mL}$ and 4.615 . $\pm 0.04 \mathrm{ng} / \mathrm{mL}$ respectively. No noteworthy variation in peak plasma concentration on eighth day (day 8) observed $(P>0.05)$. No noteworthy variation observed $t_{\max }, A U C$, and $\mathrm{T}_{1 / 2}$ for single drugs and combination. And there is no significant difference in pharmacodynamic parameters also.

\section{Study of Pharmacokinetic Parameters (PK) of Gliclazide and Pravastatin}

Different PK parameters of gliclazide, pravastatin alone and combined treated parameters were studies in this study. Pharmacokinetic parameters were studied.

The PK parameters of gliclazide alone and in combination with pravastatin on first day (day 1 ), gliclazide alone parameters are $\mathrm{C}_{\max } 6.82 \pm 0.12 \mathrm{ng} / \mathrm{mL}$, $\mathrm{t}_{\max } 4 \pm 0 \mathrm{~h}, \mathrm{AUC}_{\mathrm{o-t}}, 72.45 \pm 0.74 \mathrm{ng} / \mathrm{mL} / \mathrm{h}, \mathrm{AUC}_{\mathrm{o} \text {-inf, }}, 96.82 \pm$ $2.50 \mathrm{ng} / \mathrm{mL} / \mathrm{h}, \mathrm{T}_{1 / 2} 9.56 \pm 0.28 \mathrm{~h}$. Gliclazide in combination with Pravastatin the parameters are $\mathrm{C}_{\max } 7.22 \pm 0.12 \mathrm{ng} /$ $\mathrm{mL}, \mathrm{t}_{\max } 4 \pm 0 \mathrm{~h}, \mathrm{AUC}_{\mathrm{o}-\mathrm{t}}, 81.37 \pm 0.52 \mathrm{ng} / \mathrm{mL} / \mathrm{h}, \mathrm{AUC}_{\text {o-inf, }}$ $99.15 \pm 1.85 \mathrm{ng} / \mathrm{mL} / \mathrm{h}$ and $\mathrm{T}_{1 / 2} 9.64 \pm 0.09 \mathrm{~h}$. (Table 5).

The PK parameters of gliclazide alone and in combination with pravastatin on eighth day (day 8), gliclazide alone parameters are $C_{\max } 7.82 \pm 0.12 \mathrm{ng} /$ $\mathrm{mL}, \mathrm{t}_{\max } 4 \pm 0 \mathrm{~h}, \mathrm{AUC}_{\mathrm{o}-\mathrm{t}} 87.36 \pm 2.38 \mathrm{ng} / \mathrm{mL} / \mathrm{h}, \mathrm{AUC}_{\text {o-inf }}$ $98.36 \pm 2.63 \mathrm{ng} / \mathrm{mL} / \mathrm{h}, \mathrm{T}_{1 / 2} 9.496 \pm 0.024 \mathrm{~h}$. Gliclazide in combination with pravastatin the parameters are $\mathrm{C}_{\max } 7.22$ $\pm 0.12 \mathrm{ng} / \mathrm{mL}, \mathrm{t}_{\max } 4 \pm 0 \mathrm{~h}, \mathrm{AUC}_{\mathrm{ot}} 89.38 \pm 2.49 \mathrm{ng} / \mathrm{mL} / \mathrm{h}$, $\mathrm{AUC}_{\mathrm{o} \text {-inf }} 113.49 \pm 2.74 \mathrm{ng} / \mathrm{mL} / \mathrm{h}, \mathrm{T}_{1 / 2} 9.08 \pm 0.018 \mathrm{~h}$. The results were showed in Table 6 . 
Table 5: The pharmacokinetic parameters of gliclazide and combined with pravastatin on first day (Day 1)

\begin{tabular}{lll}
\hline Parameters & Gliclazide & Gliclazide and pravastatin \\
\hline $\mathrm{C}_{\text {max }}(\mathrm{ng} / \mathrm{mL})$ & $6.82 \pm 0.12$ & $7.22 \pm 0.12$ \\
$\mathrm{t}_{\text {max }}(\mathrm{h})$ & $4 \pm 0$ & $4 \pm 0$ \\
$\mathrm{AUC}_{\text {o-t }}(\mathrm{ng} / \mathrm{mL} / \mathrm{h})$ & $72.45 \pm 0.74$ & $81.37 \pm 0.52$ \\
$\mathrm{AUC}_{\text {o- } \mathrm{inf}}(\mathrm{ng} / \mathrm{mL} / \mathrm{h})$ & $96.82 \pm 2.50$ & $99.15 \pm 1.85$ \\
$\mathrm{~T}_{1 / 2}(\mathrm{~h})$ & $9.56 \pm 0.28$ & $9.64 \pm 0.09$ \\
\hline
\end{tabular}

Table 7: Pharmacokinetic parameters of pravastatin and combined with gliclazide on first day (Day 1 )

\begin{tabular}{lll}
\hline Parameters & Pravastatin & $\begin{array}{l}\text { Pravastatin and } \\
\text { Gliclazide }\end{array}$ \\
\hline $\mathrm{C}_{\max }(\mathrm{ng} / \mathrm{mL})$ & $3.92 \pm 0.03$ & $3.683 \pm 0.02$ \\
$\mathrm{t}_{\text {max }}(\mathrm{h})$ & $1 \pm 0$ & $1 \pm 0$ \\
$\mathrm{AUC}_{\mathrm{o}-\mathrm{t}}(\mathrm{ng} / \mathrm{mL} / \mathrm{h})$ & $33.49 \pm 0.016$ & $31.62 \pm 0.20$ \\
$\mathrm{AUC}_{\mathrm{o}-\mathrm{inf}}(\mathrm{ng} / \mathrm{mL} / \mathrm{h})$ & $52.33 \pm 1.37$ & $42.16 \pm 0.52$ \\
$\mathrm{~T}_{1 / 2}(\mathrm{~h})$ & $2.50 \pm 0.49$ & $2.50 \pm 0.27$ \\
\hline
\end{tabular}

Table 6: Pharmacokinetic parameters of gliclazide alone and combined with pravastatin on eighth day (Day 8)

\begin{tabular}{lll}
\hline Parameters & Gliclazide & Gliclazide and pravastatin \\
\hline $\mathrm{C}_{\max }(\mathrm{ng} / \mathrm{mL})$ & $7.82 \pm 0.12$ & $7.22 \pm 0.12$ \\
$\mathrm{t}_{\max }(\mathrm{h})$ & $4 \pm 0$ & $4 \pm 0$ \\
$\mathrm{AUC}_{\mathrm{o}-\mathrm{t}}(\mathrm{ng} / \mathrm{mL} / \mathrm{h})$ & $87.36 \pm 2.38$ & $89.38 \pm 2.49$ \\
$\mathrm{AUC}_{\mathrm{o}-\mathrm{inf}}(\mathrm{ng} / \mathrm{mL} / \mathrm{h})$ & $98.36 \pm 2.63$ & $113.49 \pm 2.74$ \\
$\mathrm{~T}_{1 / 2}(\mathrm{~h})$ & $9.496 \pm 0.024$ & $9.08 \pm 0.018$ \\
\hline
\end{tabular}

Table 8: Pharmacokinetic parameters of pravastatin alone and combined with gliclazide on eighth day (Day 8) $(\mathrm{N}=6)$

\begin{tabular}{lll}
\hline Parameters & $\begin{array}{l}\text { Pravastatin } \\
\text { alone }\end{array}$ & $\begin{array}{l}\text { Pravastatin in combination } \\
\text { with Gliclazide }\end{array}$ \\
\hline $\mathrm{C}_{\max }(\mathrm{ng} / \mathrm{mL})$ & $4.80 \pm 0.04$ & $4.657 \pm 0.04$ \\
$\mathrm{t}_{\max }(\mathrm{h})$ & $1 \pm 0$ & $1 \pm 0$ \\
$\mathrm{AUC}_{\mathrm{o}-\mathrm{t}}(\mathrm{ng} / \mathrm{mL} / \mathrm{h})$ & $33.5 \pm 0.22$ & $45.6 \pm 1.25$ \\
$\mathrm{AUC}_{\mathrm{o}-\mathrm{inf}}(\mathrm{ng} / \mathrm{mL} / \mathrm{h})$ & $52.6 \pm 0.43$ & $61.76 \pm 1.88$ \\
$\mathrm{~T}_{1 / 2}(\mathrm{~h})$ & $2.50 \pm 0.18$ & $2.50 \pm 0.29$ \\
\hline
\end{tabular}

Table 9: Fasting serum glucose concentrations in control and stz-induced diabetic animals on first day (DAY 1)

\begin{tabular}{|c|c|c|c|c|c|c|c|}
\hline \multirow[b]{2}{*}{ Group } & \multicolumn{7}{|c|}{ Serum glucose $\mathrm{mg} / \mathrm{dl}$} \\
\hline & $O h$ & $1 \mathrm{~h}$ & $2 h$ & $4 h$ & $8 h$ & $12 \mathrm{~h}$ & $24 h$ \\
\hline Normal & $95.76 \pm 0.24$ & $96.2 \pm 0.21$ & $96.86 \pm 0.47$ & $97.3 \pm 0.26$ & $97.96 \pm 0.29$ & $98.65 \pm 0.15$ & $97.68 \pm 0.44$ \\
\hline $\begin{array}{l}\text { Diabetic } \\
\text { Control }\end{array}$ & $262.16 \pm 7.96 \mathrm{~b}$ & $266.5 \pm 7.39 \mathrm{~b}$ & $275.5 \pm 7.2 \mathrm{~b}$ & $285 \pm 7.42 \mathrm{~b}$ & $296.16 \pm 6.84 \mathrm{~b}$ & $316.5 \pm 4.61 b$ & $326.16 \pm 4.76 \mathrm{~b}$ \\
\hline $\begin{array}{l}\text { Gliclazide } \\
\text { alone }\end{array}$ & $243 \pm 3.36$ & $164.83 \pm 5.36^{* *} a$ & $86 \pm 4.09^{* *} \mathrm{a}$ & $89.5 \pm 3.48^{* *} \mathrm{a}$ & $94.00 \pm 2.06^{* *} \mathrm{a}$ & $96.35 \pm 1.75^{* *} \mathrm{a}$ & $140 \pm 4.09^{* *} \mathrm{a}$ \\
\hline $\begin{array}{l}\text { Gliclazide } \\
\text { with } \\
\text { Pravastatin }\end{array}$ & $243 \pm 3.36$ & $163.83 \pm 5.36^{* *} \mathrm{a}$ & $84 \pm 4.09^{* *} \mathrm{a}$ & $87.5 \pm 3.48^{* *} \mathrm{a}$ & $89.00 \pm 2.06^{* *} \mathrm{a}$ & $90.35 \pm 1.75^{* *} \mathrm{a}$ & $137 \pm 4.09^{* *} \mathrm{a}$ \\
\hline
\end{tabular}

$\mathrm{n}=6$; Values are expressed as mean \pm S.E.M

${ }^{\mathrm{a}} \mathrm{p}<0.001 ;{ }^{\mathrm{c}} \mathrm{p}<0.05$ Vs Normal

${ }_{\mathrm{b}}^{\mathrm{p}}<0.001$ vs Diabetic Control

The PK parameters of pravastatin alone and in combination with gliclazide on first day (day 1), pravastatin alone parameters are $\mathrm{C}_{\max } 3.92 \pm 0.03 \mathrm{ng} / \mathrm{mL}, \mathrm{t}_{\max } 1 \pm 0 \mathrm{~h}, \mathrm{AUC}_{\mathrm{o}-\mathrm{t}}$ $33.49 \pm 0.016 \mathrm{ng} / \mathrm{mL} / \mathrm{h}, \mathrm{AUC}_{\text {o-inf }} 52.33 \pm 1.37 \mathrm{ng} / \mathrm{mL} / \mathrm{h}, \mathrm{T}_{1 / 2}$ $2.50 \pm 0.49 \mathrm{~h}$. Pravastatinin combination with gliclazide the parameters are $\mathrm{C}_{\max } 3.783 \pm 0.02 \mathrm{ng} / \mathrm{mL}, \mathrm{t}_{\max } 1 \pm 0$ $\mathrm{h}, \mathrm{AUC}_{\text {o-t }} 31.62 \pm 0.20 \mathrm{ng} / \mathrm{mL} / \mathrm{h}, \mathrm{AUC}_{\mathrm{o} \text {-inf }} 42.16 \pm 0.52$ $\mathrm{ng} / \mathrm{mL} / \mathrm{h}, \mathrm{T}_{1 / 2} 2.50 \pm 0.27 \mathrm{~h}$. The results were showed in Table 7.

The PK parameters of pravastatin alone and in combination with gliclazide on eighth day (day 8), pravastatin alone parameters are $\mathrm{C}_{\max } 4.80 \pm 0.04 \mathrm{ng} / \mathrm{mL}$, $\mathrm{t}_{\max } 1 \pm 0 \mathrm{~h}, \mathrm{AUC}_{\text {o-t }} 33.5 \pm 0.22 \mathrm{ng} / \mathrm{mL} / \mathrm{h}, \mathrm{AUC}_{\mathrm{o} \text {-inf }} 52.6 \pm 0.43$ $\mathrm{ng} / \mathrm{mL} / \mathrm{h}, \mathrm{T}_{1 / 2} 2.50 \pm 0.18 \mathrm{~h}$. Pravastatinin combination with gliclazide the parameters are $\mathrm{C}_{\max } 4.615 . \pm 0.04 \mathrm{ng} /$ $\mathrm{mL}, \mathrm{t}_{\max } 1 \pm 0 \mathrm{~h}, \mathrm{AUC}_{\text {o-t }} 41.6 \pm 0.25 \mathrm{ng} / \mathrm{mL} / \mathrm{h}, \mathrm{AUC}_{\text {-inf }}$ $59.76 \pm 0.88 \mathrm{ng} / \mathrm{mL} / \mathrm{h}, \mathrm{T}_{1 / 2} 2.50 \pm 0.29 \mathrm{~h}$. The results were showed in Table 8.

Based on pharmacokinetic parameters obtained from the results gliclazide alone and gliclazide in combination with pravastatin, no noteworthy variation in gliclazide PK parameters observed. Similarly, no significant difference in pharmacokinetic parameters of pravastatin alone and combined with gliclazide observed.

\section{Pharmacodynamic Studies of Gliclazide and Pravastatin}

Pharmacodynamic results of gliclazide alone and combined with pravastatin on first day (day 1) and eighth day (day 8) was showed in Tables 9 and 10 . The glucose levels in blood samples are analyzed at $0,1,2,4,8,12$ and $24 \mathrm{~h}$ for gliclazide alone are found to be $243 \pm 3.36,164.83 \pm 5.36$, $86 \pm 4.09,89.5 \pm 3.48,94.00 \pm 2.06,6.35 \pm 1.75,140 \pm 4.09$ $\mathrm{mg} / \mathrm{dl}$ and gliclazide with pravastatin $221 \pm 4.26,130.83$ $\pm 3.36,61 \pm 4.19,62.5 \pm 2.48,80.00 \pm 1.16,92.32 \pm 1.25$, $112 \pm 4.19 \mathrm{mg} / \mathrm{dL}$. No significant difference observed in the values of gliclazide and pravastatin.

Similarly on eighth day (day 8) gliclazide alone the reduction blood glucose levels are $223 \pm 4.16,138.83 \pm$ $4.36,63 \pm 4.29,65.5 \pm 2.48,81.00 \pm 1.06,94.33 \pm 1.55$, $113 \pm 4.17 \mathrm{mg} / \mathrm{dl}$, gliclazide with pravastatin $221 \pm 4.26$, $130.83 \pm 3.36,61 \pm 4.19,62.5 \pm 2.48,80.00 \pm 1.16,92.32 \pm$ 
Pharmacokinetic and Pharmacodynamic Interactions between Concomitantly used Gliclazide with Pravastatin

Table 10: Fasting serum glucose concentrations in control and stz-induced diabetic animals on eighth day (DAY 8)

\begin{tabular}{|c|c|c|c|c|c|c|c|}
\hline \multirow[b]{2}{*}{ Group } & \multicolumn{7}{|c|}{ Serum glucose $\mathrm{mg} / \mathrm{dl}$} \\
\hline & $O h$ & $1 \mathrm{~h}$ & $2 h$ & $4 h$ & $8 h$ & $12 h$ & $24 h$ \\
\hline Normal & $95.76 \pm 0.24$ & $96.2 \pm 0.21$ & $96.86 \pm 0.47$ & $97.3 \pm 0.26$ & $97.96 \pm 0.29$ & $98.65 \pm 0.15$ & $97.68 \pm 0.44$ \\
\hline $\begin{array}{l}\text { Diabetic } \\
\text { Control }\end{array}$ & $262.16 \pm 7.96 \mathrm{~b}$ & $266.5 \pm 7.39 \mathrm{~b}$ & $275.5 \pm 7.2 \mathrm{~b}$ & $285 \pm 7.42 b$ & $296.16 \pm 6.84 \mathrm{~b}$ & $316.5 \pm 4.61 \mathrm{~b}$ & $326.16 \pm 4.76 b$ \\
\hline $\begin{array}{l}\text { Gliclazide } \\
\text { alone }\end{array}$ & $223 \pm 4.16$ & $138.83 \pm 4.36^{* *} \mathrm{a}$ & $63 \pm 4.29^{* *} \mathrm{a}$ & $65.5 \pm 2.48^{* *} \mathrm{a}$ & $81.00 \pm 1.06^{* *} \mathrm{a}$ & $94.33 \pm 1.55^{* *} \mathrm{a}$ & $113 \pm 4.17^{* *} \mathrm{a}$ \\
\hline $\begin{array}{l}\text { Gliclazide } \\
\text { with } \\
\text { Pravastatin }\end{array}$ & $221 \pm 4.26$ & $130.83 \pm 3.36^{* *} a$ & $61 \pm 4.19^{* *} \mathrm{a}$ & $62.5 \pm 2.48^{* *} \mathrm{a}$ & $80.00 \pm 1.16^{* *} a$ & $92.32 \pm 1.25^{* *} \mathrm{a}$ & $112 \pm 4.19^{* *} \mathrm{a}$ \\
\hline
\end{tabular}

$\mathrm{n}=6$; Values are expressed as mean \pm S.E.M

${ }^{\mathrm{a}} \mathrm{p}<0.001 ;{ }^{\mathrm{c}} \mathrm{p}<0.05$ Vs Normal

${ }^{\mathrm{b}} \mathrm{p}<0.001$ vs Diabetic Control

$1.25,112 \pm 4.19 \mathrm{mg} / \mathrm{dL}$. Here also there is no significant difference for alone and combined treatment. From the above results there is no significant difference for pharmacodynamics of alone and combined treatment of gliclazide and pravastatin.

\section{DisCUSSION}

The safety of gliclazide (anti-diabetic) therapy by pravastatin (anti-hyperlipidemic) in rats is evaluated in present research. Studies conducted on rats dosed with gliclazide, pravastatin, and combination of both. The pharmacokinetic pharmacodynamics study among gliclazide, pravastatin and the combination carried out. The plasma concentration-responses was obtained from student's paired t-test with $\mathrm{p}<0.05$ considered as statistically significant. The results reveal no significant difference in the values of peak plasma concentration, $t_{\text {max }}$ AUC, and $T_{1 / 2}$ for both drugs alone and combination treatment. No significant difference in pharmacodynamics parameters observed.

The present study states that administration of gliclazide with pravastatin is highly efficient in treatment of diabetes and hyperlipidemia. The pharmacokinetic and pharmacodynamics interactions of combined drug administration are found safe and advantageous.

\section{REFERENCES}

1. Alvim MM, Silva LA, Leite IC, Silvério MS. Adverse events caused by potential drug-drug interactions in an intensive care unit of a teaching hospital. Rev Bras Ter Intensiva. 2015; 27:353-359.

2. Moura C, Prado N, Acurcio F. Potential drug-drug interaction associated with prolonged staysin the intensive care unit: a retrospective cohort study. Clin Drug Investig. 2011; 31:309-316.
3. Bussing R, Gende A. Severe hypoglycemia from clarithromycinsulfonylurea drug interaction. Diabetes Care 2002; 25(9): 1659-1661.

4. Gribble FM, Tucker SJ, Seino S, Ashcroft FM. Tissue specificity of sulfonylureas studies on cloned cardiac and $\beta$ cell KATP channels. Diabetes 1998;47(9): 1412-1418.

5. Harrower D. Efficacy of gliclazide in comparison with other sulphonylureas in the treatment of NIDDM. Diabetes Res Clin Pract. 1991; 14(2): S65-S67.

6. Ziegler 0, Drouin P. Hemobiological properties of gliclazide. J Diabetes Complications. 1994; 8(4): 235-239.

7. Pan HY, DeVault AR, Swites BJ. Pharmacokinetics and pharmacodynamics of pravastatin alone and with cholestyramine in hypercholesterolemia. Clin Pharmacol and Therap. 1990; 48(2): 201-207.

8. Hsu, Spinler SA, Johnson NE. Comparative evaluation of the safety and efficacy of HMG-CoA reductase inhibitor monotherapy in the treatment of primary hypercholesterolemia. Ann Pharmacother. 1995; 29(7-8):743-759.

9. Hatanaka T. Clinical pharmacokinetics of Pravastatin mechanisms of pharmacokinetic events. Clin Pharmacokinet. 2000; 39(6): 397-412.

10. Jacobsen W, Kirchner G, Hallensleben K. Comparison of cytochrome P-450-dependent metabolism and drug interactions of the 3-hydroxy-3-methylglutaryl-CoA reductase inhibitors lovastatin and pravastatin in the liver. Drug Metab Dispos. 1999; 27(2): 173-179. Ref: https://pubmed.ncbi.nlm.nih.gov/9929499/

11. Transon C, LeemannT, Dayer P. In vitro comparative inhibition profiles of major human drug metabolising cytochrome P450 isozymes (CYP2C9, CYP2D6 and CYP3A4) by HMG-CoA reductase inhibitors. Eur J Clin Pharmacol. 1996; 50 (3): 209-215.

12. Nagy CF. Concurrent administration of donepezil $\mathrm{HCl}$ and sertraline $\mathrm{HCl}$ in healthy volunteers: assessment of pharmacokinetic changes and safety following single and multiple oral doses. Br J Clin Pharmacol. 2004; 58: 25-33.

13. Davit BM. Comparing generic and innovator drugs: a review of 12 years of bioequivalence data from the United States Food and Drug Administration. Ann Pharmacother. 2009; 43: 1583-1597.

14. Meredith P. Bioequivalence and other unresolved issues in generic drug substitution. Clin Ther. 2003; 25: 2875-2890.

HOW TO CITE THIS ARTICLE: Haseeb TSA, Reddy TRM. Pharmacokinetic and Pharmacodynamic Interactions between Concomitantly used Gliclazide with Pravastatin. Int. J. Pharm. Sci. Drug Res. 2020;12(6):682-687. DOI: 10.25004/IJPSDR.2020.120612 